\title{
Virulence of Starved Aeromonas hydrophila to Cyprinid Fish
}

\author{
M. Habibur Rahman, Kenji Kawai* and Riichi Kusuda \\ Fish Disease Laboratory, Department of Aquaculture, Kochi University, Nankoku, Kochi 783, Japan
}

(Received March 3, 1997)

\begin{abstract}
The survival of Aeromonas hydrophila was studied in a variety of waters containing different concentrations of salts. The survival of $A$. hydrophila for a period of $120 \mathrm{~h}$ was found to be optimal at 0.85 and $0.35 \% \mathrm{NaCl}, 1 \%$ $\mathrm{KCl}, 0.2 \% \mathrm{CaCl}_{2} \cdot 2 \mathrm{H}_{2} \mathrm{O}$ or $0.4 \% \mathrm{MgCl}_{2} \cdot 6 \mathrm{H}_{2} \mathrm{O}$, respectively. Among the formulated salt water solutions examined, the best survival was found in that containing $0.60 \% \mathrm{NaCl}, 0.50 \% \mathrm{KCl}, 0.10 \% \mathrm{CaCl}_{2} \cdot 2 \mathrm{H}_{2} \mathrm{O}$ and $0.20 \% \mathrm{MgCl}_{2} \cdot 6 \mathrm{H}_{2} \mathrm{O}$ in distilled water $\left(\mathrm{FW}_{2}\right)$. Virulence of the bacterium starved for $24 \mathrm{~h}$ in $\mathrm{FW}_{2}$ and $0.85 \% \mathrm{NaCl}$ was compared to that of the bacterium cultured in nutrient broth to carp and goldfish by intraperitoneal injection. The median lethal dose obtained by the infection verified that the bacterium starved in both salt solutions had obviously higher virulence than the cultured bacterium.
\end{abstract}

Key words: Aeromonas hydrophila, survival, starvation, virulence, cyprinid fish

Aquatic environments are the primary habitat of Aeromonas species (Hazen et al., 1978; Hazen and Esch, 1983). The wide distribution of Aeromonas species is probably a consequence of its high capacity to adapt different aquatic environment (Mateos et al., 1993). It seems that these bacteria have basically survival capacity in different qualities of waters (Kersters et al., 1996). The survival of the pathogen for a long period of time in the environmental water is thought to contribute to an outbreak of the disease; however, infectivity of the pathogen surviving in the water has not been elucidated. This knowledge will help fish culturists to take the necessary measures of prevention and control against the infections (Chowdhury and Wakabayashi, 1988). Wakabayashi and Egusa (1972) reported that Flexibactor columnaris could survive for a long time in tap water presuming that the different salts dissolved in natural waters, $\mathrm{Na}^{+}, \mathrm{K}^{+}, \mathrm{Ca}^{+}$and $\mathrm{Mg}^{++}$might have influenced the survivability and virulence of $F$. columnaris. The similar phenomena will be observed in A. hydrophila.

A. hydrophila is the causative agent of haemorrahagic septicaemia (Haley et al., 1967) and ulcerative disease of fishes (Karunasagar et al., 1995). There are many informations of pathogenicity of A. hydrophila (Austin and Austin, 1993; Thune et al., 1993; Angka et al., 1995), however these results were obtained by using the bacteria which are cultured in nutritious media. It is not likely

* Author to whom correspondence should be addressed that infecting bacteria are always in a nutritious conditions but mostly they exist in a starved condition outside of the host fish. Therefore it is essential to determine if the starved bacteria sustain pathogenicity enough to infect fish. From this view point, the present study aimed to compare the pathogenicity of cultured and starved A. hydrophila.

\section{Materials and methods}

\section{Test waters}

Eight kinds of waters were prepared for testing survival of the bacterium; (1) distilled water (DW), (2) river water, (3) tap (well) water, (4) $\mathrm{NaCl}$ solution in DW, (5) $\mathrm{KCl}$ solution in DW, (6) $\mathrm{CaCl}_{2} \cdot 2 \mathrm{H}_{2} \mathrm{O}$ solution in DW, (7) $\mathrm{MgCl}_{2} \cdot 6 \mathrm{H}_{2} \mathrm{O}$ solution in DW, and (8) formulated water (FW) composed of combinations of above salts. The initial concentration of $\mathrm{Na}^{+}, \mathrm{K}^{+}, \mathrm{Ca}^{+}$ and $\mathrm{Mg}^{++}$in the test waters were based on gross sea water and the four successive dilutions were made i.e. 3.5$0.0085 \%$ of $\mathrm{NaCl}, 1-0.001 \%$ of $\mathrm{KCl}, 0.2-0.0002 \%$ of $\mathrm{CaCl}_{2} \cdot 2 \mathrm{H}_{2} \mathrm{O}$ and $0.4-0.0004 \%$ of $\mathrm{MgCl}_{2} \cdot 6 \mathrm{H}_{2} \mathrm{O}$. Formulated waters were designed from the results of survivability of the bacteria in single salt solutions, such as; $\mathrm{FW}_{1}$ containing $1.20 \% \mathrm{NaCl}, 1 \% \mathrm{KCl}, 0.20 \%$ $\mathrm{CaCl}_{2} \cdot 2 \mathrm{H}_{2} \mathrm{O}$ and $0.40 \% \mathrm{MgCl}_{2} \cdot 6 \mathrm{H}_{2} \mathrm{O}$ in distilled water; $\mathrm{FW}_{2}$ containing $0.60 \% \mathrm{NaCl}, 0.50 \% \mathrm{KCl}, 0.10 \%$ $\mathrm{CaCl}_{2} \cdot 2 \mathrm{H}_{2} \mathrm{O}$ and $0.20 \% \mathrm{MgCl}_{2} \cdot 6 \mathrm{H}_{2} \mathrm{O} ; \mathrm{FW}_{3}$ containing $0.30 \% \mathrm{NaCl}, 0.25 \% \mathrm{KCl}, 0.05 \% \mathrm{CaCl}_{2} \cdot 2 \mathrm{H}_{2} \mathrm{O}$ and $0.10 \%$ 
$\mathrm{MgCl}_{2} \cdot 6 \mathrm{H}_{2} \mathrm{O}$ in distilled water; $\mathrm{FW}_{4}$ containing $0.15 \%$ $\mathrm{NaCl}, 0.13 \% \mathrm{KCl}, 0.025 \% \mathrm{CaCl}_{2} \cdot 2 \mathrm{H}_{2} \mathrm{O}$ and $0.05 \%$ $\mathrm{MgCl}_{2} \cdot 6 \mathrm{H}_{2} \mathrm{O}$ in distilled water. All experimental water solutions were sterilized at $121^{\circ} \mathrm{C}$ for $15 \mathrm{~min}$ before used.

\section{Bacteria}

A. hydrophila strain A-3500 originally isolated from an eel was passed in colored (golden) carp Cyprinus carpio several times to increase the pathogenicity before starting experiment. Reisolated bacteria were lyophilized and stocked in $10 \%$ skimed milk at $-80^{\circ} \mathrm{C}$ until used.

\section{Preperation of cultured bacteria}

The bacteria were cultured in nutrient broth "Nissui" at $25^{\circ} \mathrm{C}$ for $24 \mathrm{~h}$. Bacterial cells were harvested by centrifugation at $3,000 \times g$ for $20 \mathrm{~min}$ and washed twice in physiological saline $(0.85 \% \mathrm{NaCl}, \mathrm{PS})$. After washed, suitable concentrations of bacteria for inoculation or injection were made.

\section{Preperation of starved bacteria}

Washed bacterial cells were suspended in $\mathrm{PS}$ and $\mathrm{FW}_{2}$ then incubated at $15^{\circ} \mathrm{C}$ for $24 \mathrm{~h}$. After one day starvation in PS and $\mathrm{FW}_{2}$, suitable concentrations of bactaria for inoculation or injection were made.

\section{Survival test}

One hundred mililiter of each kind of water was autoclaved and cooled at room temperature (about $25^{\circ} \mathrm{C}$ ). After cooled bacterial suspension was diluted by 10 fold dilution in PS to make a concentration of about $10^{7} \mathrm{CFU} /$ $\mathrm{ml}$ then $0.1 \mathrm{ml}$ of bacterial suspension was inoculated into each water solution and incubated at $25^{\circ} \mathrm{C}$ for $24 \mathrm{~h}$. Bacterial viable count was made on nutrient agar at appropriate intervals by using the agar spread method. Slide agglutination test was carried out to confirm purity of the bacteria using a rabbit antiserum against $A$. hydrophila A-3500 strain.

\section{Pathogenecity test}

Three types of cyprinid fish; 2 races of carp "ougon" (golden colored carp) and "kouhaku" (red and white colored carp) and goldfish Carassius auratus were used to compare pathogenicity of cultured and starved bacteria. Fish weighing 10-20 $\mathrm{g}$ were obtained from a fish farm in Kochi Prefecture, Japan. The fish were kept in $600 l$ tanks with well aerated flow water until used. The fish were fed commercial food pellets. Different concentrations of starved and cultured bacteria were made in PS by 10 fold dilution, then injected intra- peritoneally into 5 ougon carp groups, each consisting of 5 fish, 5 kouhaku carp groups, each consisting of 8 fish and 5 goldfish groups, each consisting of 6 fish. Injected fish were reared for 15 days between 20 to $25^{\circ} \mathrm{C}$ and mortality was recorded. Infetion was confirmed by reisolating the bacteria from the kidney of dead fish using nutrient agar and slide agglutination test on the reisolated bacteria. Finally the median lethal dose $\left(\mathrm{LD}_{50}\right)$ was calculated by the method of Reed and Muench (1938).

\section{Results}

Survival of bacteria in various water solutions

The survival of $A$. hydrophila in distilled, river and tap waters are shown in Fig. 1. The viable bacteria in tap and river waters increased in number slightly at $48 \mathrm{~h}$ and $72 \mathrm{~h}$ post-inoculation (P.I.) and then decreased until the end of experimental period. On the other hand the viable bacteria in distilled water decreased in number at 24 h P.I. and was not detected thereafter.

Out of $6 \mathrm{NaCl}$ solutions the hightest survival was observed in 0.85 and $0.35 \% \mathrm{NaCl}$ (Fig. 2A). The bacteria decreased in number at the first day then increased towards $48 \mathrm{~h}$ and a static survival was maintained until $120 \mathrm{~h}$. But the bacteria decreased in 3.5, 0.035, 0.085 and $0.0085 \% \mathrm{NaCl}$ solutions from the initial through $120 \mathrm{~h}$. In case of $\mathrm{KCl}$ the highest survival was obtained in $1 \%$ solution (Fig. 2B). The bacteria

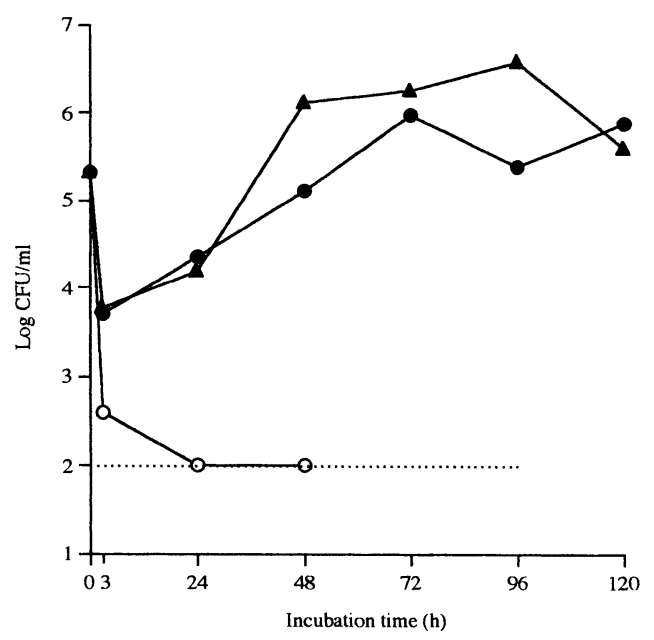

Fig. 1. Survival of Aeromonas hydrophila strain A-3500 in river $(\mathbf{O}), \operatorname{tap}(\boldsymbol{\Delta})$ and distilled waters $(\bigcirc) . \ldots \ldots$, detection limit. 


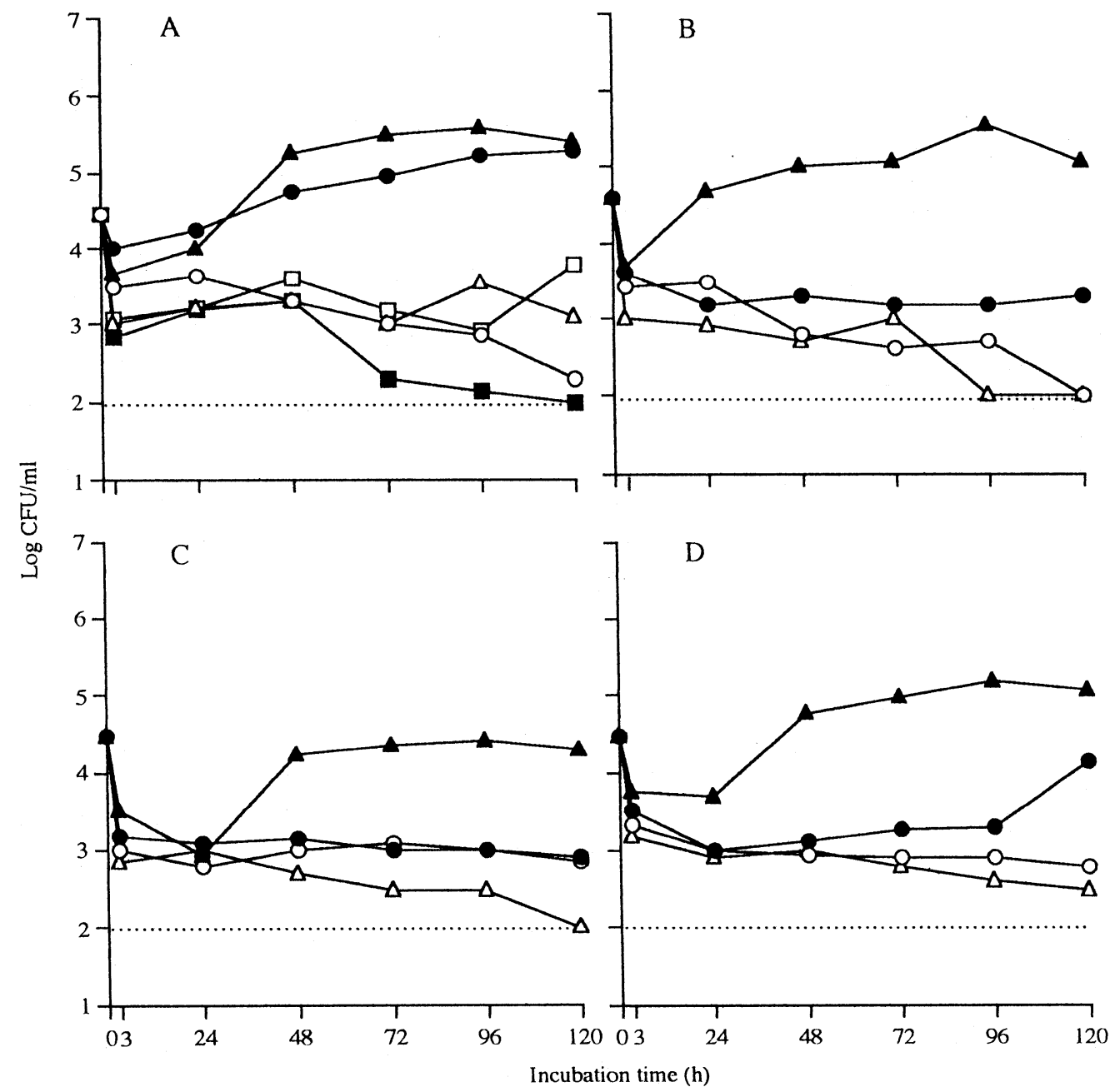

Fig. 2. Survival of cultured Aeromonas hydrophila strain A-3500 in various salt solutions. $\mathrm{A}: \mathrm{NaCl}(\bigcirc, 3.5 \% ; \mathbf{\Delta}, 0.85 \%$; $0.35 \% ; \square, 0.085 \% ; \triangle, 0.035 \% ; \square, 0.0085 \%) ; \mathrm{B}: \mathrm{KCl}(\boldsymbol{\Delta}, 1 \% ; \bigcirc, 0.1 \% ; \bigcirc, 0.01 \% ; \triangle, 0.001 \%) ; \mathrm{C}^{-} \mathrm{CaCl}_{2}(\mathbf{\Delta}, 0.2 \% ;$ $0.02 \% ; \bigcirc, 0.002 \% ; \triangle, 0.0002 \%) ; \mathrm{D}: \mathrm{MgCl}_{2}(\mathbf{\Delta}, 0.4 \% ; \mathbf{O}, 0.04 \% ; \bigcirc, 0.004 \% ; \triangle, 0.0004 \%)$......, detection limit.

decreased in $3 \mathrm{~h}$ and then increased until $96 \mathrm{~h}$. The bacteria decreased in $0.1,0.01$ and $0.001 \% \mathrm{KCl}$ solutions. The survival of $A$. hydrophila in $0.1,0.01$, and 0.001 $\mathrm{KCl}$ solutions were almost similar until $120 \mathrm{~h}$. In case of $\mathrm{CaCl}_{2} \cdot 2 \mathrm{H}_{2} \mathrm{O}$ solutions, the highest survival was observed in $0.2 \% \mathrm{CaCl}_{2} \cdot 2 \mathrm{H}_{2} \mathrm{O}$ (Fig. 2C). The bacteria decreased until $24 \mathrm{~h}$ and then increased and the survival was static through $120 \mathrm{~h}$. The survival in $0.02,0.002$ and $0.0002 \% \mathrm{CaCl}_{2} \cdot 2 \mathrm{H}_{2} \mathrm{O}$ solutions were similar. Among the $\mathrm{MgCl}_{2} \cdot 6 \mathrm{H}_{2} \mathrm{O}$ solutions the survival was the highest in $0.4 \%$ solution (Fig. 2D). The bacteria decreased at $3 \mathrm{~h}$ and $24 \mathrm{~h}$ and then the number was increased through $120 \mathrm{~h}$. The survival at $0.040,0.0040$ and $0.0004 \% \mathrm{MgCl}_{2} \cdot 6 \mathrm{H}_{2} \mathrm{O}$ solutions were similar to each other through $120 \mathrm{~h}$. Out of 4 different formulated waters the highest survival of $A$. hydrophila was observed in $\mathrm{FW}_{2}$ (Fig. 3). The survival was lowest in $\mathrm{FW}_{1}$ and almost similar in $\mathrm{FW}_{3}$ and $\mathrm{FW}_{4}$.

\section{Pathogenicity of starved and cultured bacteria}

Starved bacteria in $\mathrm{FW}_{2}$ and $0.85 \% \mathrm{NaCl}$ solution were used from the result in the previous experiment of 


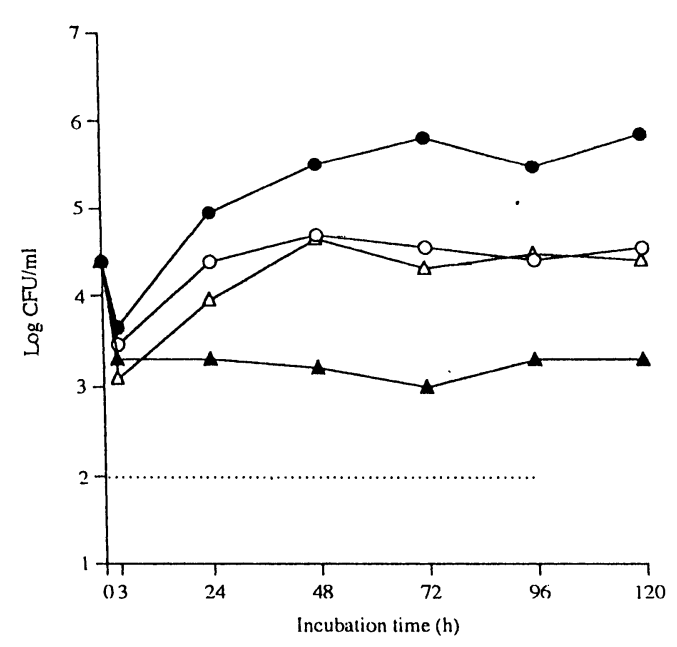

Fig. 3. Survival of cultured Aeromonas hydrophila strain A3500 in various formulated waters. Formulated water $1(\boldsymbol{\Delta})$, formulated water $2(\boldsymbol{O})$, formulated water $3(\bigcirc)$ and formulated water $4(\triangle)$......, detection limit.

survival. The pathogenicity of starved and cultured bacteria determined after intraperitoneal injection to three kinds of fish is summarized in Table 1. The $\mathrm{LD}_{50}$ of starved bacteria were $10^{6.75}\left(\mathrm{FW}_{2}\right)$ and $10^{6.57}(\mathrm{PS})$ in ougon carp, $10^{6.13}\left(\mathrm{FW}_{2}\right)$ and $10^{6.38}(\mathrm{PS})$ in kouhako carp and $10^{6.15}\left(\mathrm{FW}_{2}\right)$ and $10^{6.05}(\mathrm{PS})$ in goldfish. The $\mathrm{LD}_{50}$ of cultured bacteria was $10^{7.90}$ in ougon carp, $10^{7.69}$ in kouhaku carp and $10^{7.39}$ in goldfish. Pathogenicity of starved bacteria is obviously higher than that of the cultured bacteria in all kinds of fishes.

\section{Discussion}

The survivability study demonstrated the high survival rate or some proliferation of A. hydrophila in the solution with $0.35 \%$ and $0.85 \% \mathrm{NaCl}, 1 \% \mathrm{KCl}, 0.20 \%$ $\mathrm{CaCl}_{2} \cdot 2 \mathrm{H}_{2} \mathrm{O}, 0.40 \% \mathrm{MgCl}_{2} \cdot 6 \mathrm{H}_{2} \mathrm{O}, \mathrm{FW}_{2}$, river and tap water preperations. In case of $\mathrm{NaCl}$ and $\mathrm{FW}_{\mathrm{s}}$ the bacteria could not survive long period in high concentrations of salts. There was a decline in the viable count between 0 and $3 \mathrm{~h}$ in all the preperations of water. There are reports on the long time survival of $A$. hydrophila in filtered lake water (Lowcock and Edwards, 1994) and in low nutrient waters (Van der Kooij and Hijnen, 1984). One of the reason for the ecologically broad distribution of A. hydrophila may be attributed to its survivability as described by Kersters et al., (1996). Morita (1982) suggested that $1 \%$ or less of bacterial cells could survive for a long period of time under starvation in the absence of an exogenous carbon source.

From etiological and epizootiological view points of pathogenic microorganisms, it is important to establish whether any of their physiological characteristics, either singly or in combination, can be related to virulence (Santos et al., 1987). Starvation survival is a mechanism by which the species can control the time of exsistance analogous to bacterial spore (Dow et al., 1983). Drastic changes take place in the lipid content of Vibrio cholerae in the membrane when cells are starved since phospholipids located in the membrane are metabolized (Hood et al., 1986). During the period of starvation, the cis-monoenoic fatty acids are preferentially utilized in V. cholerae (Guckert et al., 1986). Amy and Morita (1983) demonstrated that starved cells of Vibrio sp. lose many proteins, however they synthesize new proteins. These newly synthesized proteins were termed starvation protein. Carbon starvation results in an increase in the degree of cross linking in the murein layer in Gram negative bacteria (Pisabarro et al., 1985). An increase in the thickness of the peptidoglycan layer has also been demonstrated by shifting from 2 to 3 layers of peptidoglycan to 4 to 5 layers in Escherichia coli (Leduc et al., 1989). Starved Vibrio strains possess a large number of exoenzymes that allow efficient degradetion of a variety of polymeric substances in the environment even in the host surface tissue, which will enable the bacterium to infect human and marine vertebrates and invertebrates (Davis, 1992). It is assumed that similar physiological changes reported in Vibrio sp. occured in starved A. hydrophila. Based on the results of this study it may be concluded that the starved A. hydrophila is more pathogenic than the cultured A. hydrophila.

\section{Aknowledgements}

The authors are thankful to Dr. Yano, Kyushu University for supplying the bacterial strain and the first author is grateful to the Monbusho for Scholarship support.

\section{References}

Amy, P. S. and R. Y. Morita (1983): Protein patterns of growing and starved cells of a marine Vibrio sp. Appl. Environ. Microbiol., 45, 1685-1690.

Angka, S. L.,T. L. Lam and Y. M. Sin (1995): Some virulence characteristics of Aeromonas hydrophila in walking catfish (Clarias gariepinus). Aquaculture, 130, 103-112. 
Table 1. Virulence of starved and cultured Aeromonas hydrophila strain A-3500 after intraperitoneal injection to three kinds of fish

\begin{tabular}{|c|c|c|c|c|c|}
\hline Name of fish & Bacterium & CFU/fish & Dead fish/injected fish & Mortality (\%) & $\mathrm{LD}_{50}$ \\
\hline \multirow{15}{*}{ Ougon carp } & \multirow{5}{*}{ Starved in $\mathrm{FW}_{2}$} & $1.2 \times 10^{8}$ & $4 / 5$ & 80 & \multirow{5}{*}{$10^{6.75}$} \\
\hline & & $1.2 \times 10^{7}$ & $3 / 5$ & 60 & \\
\hline & & $1.2 \times 10^{6}$ & $2 / 5$ & 40 & \\
\hline & & $1.2 \times 10^{5}$ & $0 / 5$ & 0 & \\
\hline & & $1.2 \times 10^{4}$ & $0 / 5$ & 0 & \\
\hline & \multirow{5}{*}{ Starved in PS } & $1.3 \times 10^{8}$ & $4 / 5$ & 80 & \multirow{5}{*}{$10^{6.57}$} \\
\hline & & $1.3 \times 10^{7}$ & $4 / 5$ & 80 & \\
\hline & & $1.3 \times 10^{6}$ & $2 / 5$ & 40 & \\
\hline & & $1.3 \times 10^{5}$ & $0 / 5$ & 0 & \\
\hline & & $1.3 \times 10^{4}$ & $0 / 5$ & 0 & \\
\hline & \multirow{5}{*}{ Cultured } & $2.3 \times 10^{8}$ & $3 / 5$ & 60 & \multirow{5}{*}{$10^{7.90}$} \\
\hline & & $2.3 \times 10^{7}$ & $1 / 5$ & 20 & \\
\hline & & $2.3 \times 10^{6}$ & $1 / 5$ & 20 & \\
\hline & & $2.3 \times 10^{5}$ & $0 / 5$ & 0 & \\
\hline & & $2.3 \times 10^{4}$ & $0 / 5$ & 0 & \\
\hline \multirow{15}{*}{ Kouhaku carp } & \multirow{5}{*}{ Starved in $\mathrm{FW}_{2}$} & $2.4 \times 10^{8}$ & $8 / 8$ & 100 & \multirow{5}{*}{$10^{6.13}$} \\
\hline & & $2.4 \times 10^{7}$ & $6 / 8$ & 75 & \\
\hline & & $2.4 \times 10^{6}$ & $4 / 8$ & 50 & \\
\hline & & $2.4 \times 10^{5}$ & $4 / 8$ & 50 & \\
\hline & & $2.4 \times 10^{4}$ & $0 / 8$ & 0 & \\
\hline & \multirow{5}{*}{ Starved in PS } & $2.4 \times 10^{8}$ & $7 / 8$ & 87.5 & \multirow{5}{*}{$10^{6.38}$} \\
\hline & & $2.4 \times 10^{7}$ & $5 / 8$ & 62.5 & \\
\hline & & $2.4 \times 10^{6}$ & $5 / 8$ & 62.5 & \\
\hline & & $2.4 \times 10^{5}$ & $2 / 8$ & 25 & \\
\hline & & $2.4 \times 10^{4}$ & $0 / 8$ & 0 & \\
\hline & \multirow{5}{*}{ Cultured } & $2.2 \times 10^{8}$ & $5 / 8$ & 62.5 & \multirow{5}{*}{$10^{7.69}$} \\
\hline & & $2.2 \times 10^{7}$ & $2 / 8$ & 25 & \\
\hline & & $2.2 \times 10^{6}$ & $2 / 8$ & 25 & \\
\hline & & $2.2 \times 10^{5}$ & $1 / 8$ & 12.5 & \\
\hline & & $2.2 \times 10^{4}$ & $0 / 8$ & 0 & \\
\hline \multirow{15}{*}{ Goldfish } & \multirow{5}{*}{ Starved in $\mathrm{FW}_{2}$} & $3.0 \times 10^{8}$ & $6 / 6$ & 100 & \multirow{5}{*}{$10^{6.15}$} \\
\hline & & $3.0 \times 10^{7}$ & $5 / 6$ & 83.3 & \\
\hline & & $3.0 \times 10^{6}$ & $3 / 6$ & 50 & \\
\hline & & $3.0 \times 10^{5}$ & $3 / 6$ & 50 & \\
\hline & & $3.0 \times 10^{4}$ & $0 / 6$ & 0 & \\
\hline & \multirow{5}{*}{ Starved in PS } & $2.9 \times 10^{8}$ & $5 / 6$ & 83.3 & \multirow{5}{*}{$10^{6.05}$} \\
\hline & & $2.9 \times 10^{7}$ & $5 / 6$ & 83.3 & \\
\hline & & $2.9 \times 10^{6}$ & $4 / 6$ & 66.7 & \\
\hline & & $2.9 \times 10^{5}$ & $3 / 6$ & 50 & \\
\hline & & $2.9 \times 10^{4}$ & $0 / 6$ & 0 & \\
\hline & \multirow{5}{*}{ Cultured } & $3.4 \times 10^{8}$ & $4 / 6$ & 66.7 & \multirow{5}{*}{$10^{7.35}$} \\
\hline & & $3.4 \times 10^{7}$ & $3 / 6$ & 50 & \\
\hline & & $3.4 \times 10^{6}$ & $1 / 6$ & 16.7 & \\
\hline & & $3.4 \times 10^{5}$ & $2 / 6$ & 33.3 & \\
\hline & & $3.4 \times 10^{4}$ & $0 / 6$ & 0 & \\
\hline
\end{tabular}


Austin, B. and D. A. Austin (1993): Aeromonadaceae representatives (excluding Aeromonas salmonicida), In "Bacterial fish pathogens; Disease in farmed and wild fish" (ed. by B. Austin and D. A. Austin). Ellis Horwood Limited,Chichester, England, pp. 171-187.

Chowdhury, M. B. R. and H. Wakabayashi (1988): Effects of sodium, potassium, calcium and magnesium ions on the survival of Flexibacter columnaris in water. Fish Pathol., 23, 231-235.

Davis, C. L. (1992): Production of laminarinase and alginase by marine bacteria after starvation. FEMS Microbiol. Ecol., 86, 349-356.

Dow, C. S., R. Whittenburg and N. G. Carr (1983): The shutdown or growth precursor cell an adaption for survival in a potentially hostile environment. Symp. Soc. Gen. Microbiol., 34, 187-247.

Guckert, J. B., M. A. Hood and D. C. White (1986): Phospholipid ester-linked fatty acid profile changes during nutrient deprivation of Vibrio cholerae. Increase in cis-trans ratio and properties of cyclopropyl fatty acids. Appl. Environ. Microbiol., 52, 794-801.

Haley, R., S. P. Davis and J. M. Hyde (1967): Environmental stress and Aeromonas liquefacience in American and threadfin shed mortalities. Prog. Fish Cult., 29, 19-93.

Hazen, T. C., C. B. Fliermans, R. P. Hirsch and G. W. Esch (1978): Prevalence and distribution of Aeromonas hydrophila in United States. Appl. Environ. Microbiol., 36, 731-738.

Hazen, T. C. and G. W. Esch (1983): Effect of effluent from a nitrogen fertilizer factory and a pulp mill on the distribution and abundance of Aeromonas hydrophila in Albemarle sound, North Carolina. Appl. Environ. Microbiol., 45, 31-42.

Hood, M. A., J. B. Guckert, D. C. White and F. Deck (1986): Effect of nutrient deprivation on lipid, carbohydrates, DNA, RNA and protein levels in Vibrio cholerae. Appl. Environ. Microbiol., 52, 788-793.

Karunasagar, I.,G. Sugumar and I. Karunasagar (1995): Virulence characters of Aeromonas sp. isolated from EUSaffected fish, In "Diseases in Asian aquaculture II" (ed. by M. Shariff, J. R. Arthur and R. P. Subasinghe). Fish Health Section, Asian Fisheries Society, Manila, pp. 307-314.
Kersters, G. Huys, H. Van Duffel, M. Vancanneyt, K. Kersters and W. Verstraete (1996): Survival potential of Aeromonas hydrophila in freshwaters and nutrient-poor waters in comparison with other bacteria. J. Appl. Bacteriol., 80, 266276.

Leduc, M., C. Frehel, E. Siegel and J. Van Heijenoort (1989): Multilayered distribution of peptidoglycan in the periplasmic space of Escherichia coli. J. Gen. Microbiol., 135, 12431254.

Lowcock, D. and C. Edwards (1994): Survival of geneticallymarked Aeromonas hydrophila in water. Lett. Appl. Microbiol., 19, 121-123.

Mateos, D., J. Anguita, G. Naharro and C. Paniagua (1993): Influence of growth temperature on the production of extracellular virulence factors and pathogenecity of environmental and human strains of Aeromonas hydrophila. Appl. Bacteriol., 74, 111-118.

Morita, R. Y. (1982): Starvation survival of heterotrophs in the marine environment. Adv. Microb. Ecol., 6, 171-198.

Pisabarro, A. G., M. A. De Pedro and D. Vazquez (1985): Structural modification in the peptidoglycan of Escherichia coli associated with changes in the state of growth in the culture. J. Bacteriol., 161, 238-242.

Reed, L. J. and H. Muench (1938): A simple method of estimating fifty percent endpoints. Am. J. Hyg., 27, 493497.

Santos, Y., A. E. Toranzo, C. P. Dapazo, T. P. Nieto and J. C. Barija (1987): Relationships among virulence for fish, enterotoxigenecity, and phenotypic characteristics of motile Aeromonas. Aquaculture, 67, 29-39.

Thune, R. L., L. A. Stanley and R. K. Cooper (1993): Pathogenesis of Gram negative bacterial infections in warm water fish. Ann. Rev. Fish Dis., 3, 17-68.

Van der Kooij, D. and W. A. M. Hijnen (1984): Substrate utilization by an oxalate-consuming spirillum species in relation to its growth in ozonated water. Appl. Environ. Microbiol., 47, 551-559.

Wakabayashi, H. and S. Egusa (1972): Preliminary experiments on environmental factors influencing the prevalence of columnaris disease. Fish Pathol., 7, 58-63. 